\title{
Strategies and competences of nurses in men's health care: an integrative review
}

\author{
Estratégias e competências do enfermeiro no cuidado à saúde dos homens: revisão integrativa
}

Estrategias y competencias de la enfermera en el cuidado de la salud de los hombres: revisión integradora

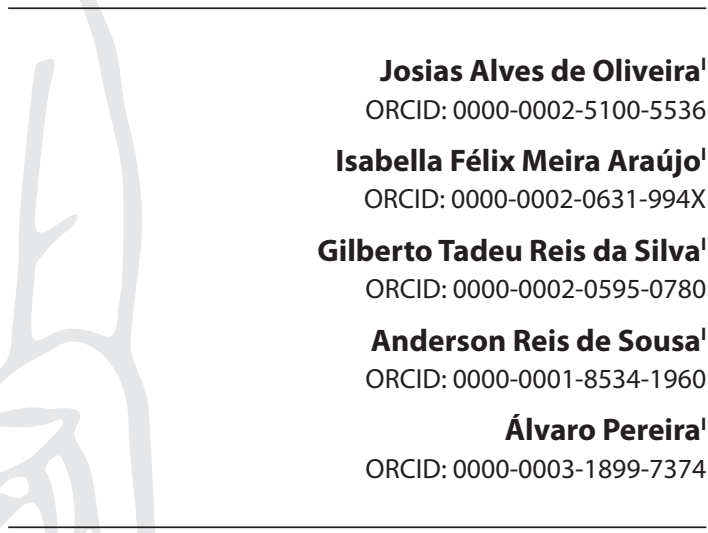

'Universidade Federal da Bahia. Salvador, Bahia, Brazil.

How to cite this article:

Oliveira JA, Araújo IFM, Silva GTR, Sousa AR, Pereira A. Strategies and competences of nurses in men's health care: an integrative review. Rev Bras Enferm. 2020;73(Suppl 6):e20190546. doi: http://dx.doi.org/10.1590/0034-7167-2019-0546

Corresponding author: Isabella Félix Meira Araújo E-mail: isabellafelixmeira@hotmail.com

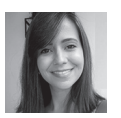

EDITOR IN CHIEF: Antonio José de Almeida Filho ASSOCIATE EDITOR: Priscilla Valladares Broca

Submission: 06-19-2019 Approval: 05-11-2020

\begin{abstract}
Objectives: to synthesize scientific evidence on nurses' strategies and competencies in men's health care. Methods: an integrative review carried out in seven databases, with a time frame from 2009 to 2019, using the descriptors "men's health","professional competence", "nursing", "nursing care" and "male" in Portuguese and in English. Results: ten articles were selected, in which it was demonstrated that nursing professionals develop their professional practices with regard to men's health care, in convergence with the general skills of the profession. The most used are health care; decision-making; Communication; administration; management; continuing education and leadership, consecutively. Final Considerations: professionals' efforts to strengthen health actions, aimed at male needs, in accordance with the general skills of the profession and the principles and guidelines of the Brazilian National Policy for Comprehensive Care to Men's Health.

Descriptors: Men's Health; Professional Competence; Strategies; Nursing Care; Nursing.
\end{abstract}

\section{RESUMO}

Objetivos: sumarizar as evidências científicas sobre as estratégias e competências de enfermeiros no cuidado à saúde dos homens. Métodos: revisão integrativa, realizada em sete bases de dados, com recorte temporal de 2009 a 2019, utilizando os descritores "saúde do homem", "competência profissional", "enfermagem", "cuidados de enfermagem" e "masculino" em português e em inglês. Resultados: selecionaram-se dez produções, nas quais demonstrou-se que profissionais de enfermagem desenvolvem suas práticas profissionais no que se refere ao cuidado à saúde dos homens, em convergência com as competências gerais da profissão, sendo as mais utilizadas: atenção à saúde; tomada de decisões; comunicação; administração; gerenciamento; Educação Permanente e liderança, consecutivamente. Considerações Finais: revelou-se o empenho dos profissionais para o fortalecimento das ações em saúde, direcionadas às necessidades masculinas, em conformidade com as competências gerais da profissão e os princípios e diretrizes da Política Nacional de Atenção Integral à Saúde do Homem.

Descritores: Saúde do Homem; Competência Profissional; Estratégias; Cuidados de Enfermagem; Enfermagem.

\section{RESUMEN}

Objetivos: resumir la evidencia científica sobre las estrategias y competencias de las enfermeras en la atención médica de los hombres. Métodos: una revisión integradora, realizada en siete bases de datos, con un marco temporal de 2009 a 2019, utilizando los descriptores "salud masculina", "competencia profesional", "enfermería", "atención de enfermería" y "masculino" en portugués y en inglés. Resultados: se seleccionaron diez producciones, en las cuales se demostró que los profesionales de enfermería desarrollan sus prácticas profesionales con respecto a la atención médica de los hombres, en convergencia con las habilidades generales de la profesión, siendo las más utilizadas: atención médica; toma de decisiones; comunicación; administración; administración; educación permanente y liderazgo, consecutivamente. Consideraciones Finales: se reveló el compromiso de los profesionales para fortalecer las acciones de salud, dirigidas a las necesidades masculinas, de acuerdo con las competencias generales de la profesión y los principios y directrices de la Política Nacional para la Atención Integral a la Salud de los Hombres.

Descriptores: Salud del Hombre; Competencia Profesional; Estrategias; Atención de Enfermería; Enfermería. 


\section{INTRODUCTION}

Men's sociocultural behaviors and behaviors in relation to health care are still major obstacles for health professionals and services ${ }^{(1)}$. Men's health remains in national and international prominence due to high rates of morbidity and mortality, high prevalence of severe conditions and chronic diseases and little male adherence in the search and use of health units, especially in the context of primary care ${ }^{(2-6)}$.

Brazilian men live, on average, 7.1 years less than women and die much more than they do due to preventable causes. According to the Brazilian Institute of Geography and Statistics (Instituto Brasileiro de Geografia e Estatística, abbreviated IBGE), male over mortality is concentrated in the group called young adults, which includes individuals aged 20 to 24 years, and in which a 20 year old man has 4.5 times more likely to not turn 25 than a woman of the same age ${ }^{(7,8)}$. This phenomenon can be explained by high incidence of deaths due to external or unnatural causes and by the risk behaviors adopted by men.

In this context, the Brazilian National Policy for Comprehensive Care to Men's Health (Política Nacional de Atenção Integral à Saúde do Homem, abbreviated PNAISH) launched in 2009, together with its guiding instrument to construct actions and strategies, the Brazilian National Action Plan (Plano de Ação Nacional, abbreviated PAN) from 2009-2011, aims at facilitating and expanding the access of men to health care actions and services, throughout the Brazilian territory, in order to favor an effective reduction of morbidity and mortality and improve the health conditions of this public ${ }^{(9,10)}$.

PNAISH directs principles in line with those of the Brazilian Health System (Sistema Único de Saúde, abbreviated SUS), referring, for instance, to humanization, quality of life and promotion of comprehensive care for men, as it allows for recognition and respect for the ethics and rights of this population, in compliance with socio-cultural peculiarities ${ }^{(10)}$. However, these principles encounter barriers for implementation in practice, since they require transformations, including sociocultural and paradigmatic ones, in the formation of specific professional competences, organization of health services, management and Brazilian public policies ${ }^{(11)}$.

When assessing the context of health practices, in addition to their broad integration of actions and strategies, both managerial and assistance, in promoting care for human beings, it is observed that nursing adds knowledge from areas of knowledge that can promote and contribute for comprehensive care for men in health services. Moreover, the work process of nurses allows professionals to act as a care manager, which requires professional skills ${ }^{(11)}$.

From this perspective, professional competencies are the ability to encompass skills, attitudes, behaviors, knowledge and values essential to the efficient performance of activities required by the nature of work. They are, therefore, essential elements for care management, demanding from health professionals the ability to perceive, analyze, act and decide in a complex system, such as that of health ${ }^{(12)}$.

Thus, the training of professional nurses must address the social needs of health, with an emphasis on SUS, in order to ensure comprehensive care and the quality and humanization of care. According to the Brazilian National Curriculum Guidelines (Diretrizes Nacionais Curriculares, abbreviated DCN) of the nursing course, undergraduate education must include the training of generalist, humanist, critical and reflective nurses, valuing the development of knowledge, skills and attitudes required for health care, decision-making, administration/management, communication, and leadership ${ }^{(13)}$.

Therefore, the relevance of the visibility of scientific production directed to nurses' skills and strategies in men's health care is evidenced and the interest in developing an integrative literature review on studies that address these competencies is justified. Therefore, it is hoped that this study can contribute to a critical reflection of nursing care practice in promoting men's health care, with the aim of improving the performance of nurses and enabling a more adequate planning of their actions, in addition to make them more participants in the care process.

\section{OBJECTIVE}

This study aims to synthetize scientific evidence on nurses' strategies and competencies in men's health care.

\section{METHOD}

This is a integrative literature review, which allows a synthesis of scientific studies and promotes knowledge about the subject ${ }^{(14)}$. It is a specific method of mapping concepts, explaining areas of research and pointing out gaps in knowledge ${ }^{(15)}$.

The study followed the six steps proposed for an integrative review: identification of the theme and selection of the research question; establishment of inclusion and exclusion criteria; categorization of studies; assessment of included studies; interpretation of results and presentation of the review/synthesis of knowledge, in line with the Revised Standards for Quality Improvement Reporting Excellence (SQUIRE 2.0) criteria $^{(14,16)}$.

For purposes of guiding the search strategy, Population, Concept and Context (PCC) ${ }^{(15)}$ strategy was used (P - "Nurse"; C - "strategies and competences"; and C- "men's health care"). Thus, based on this structure, the research was guided by the following question: what are the strategies and skills of nurses in men's health care?

The bibliographic survey was carried out from May to June 2019 by consulting Public MEDLINE, Latin American and Caribbean Literature in Health Sciences (LILACS), Nursing Database (BDENF) (through the Virtual Health Library - VHL), SCOPUS, Scientific Electronic Library Online (SciELO), Cumulative Index to Nursing and Allied Health Literature (CINAHL), and Web of Science.

Furthermore, in order to reach publications on this theme, we sought to select studies using the health descriptors (DeCs): "men's health", "professional competence", "nursing", "nursing care" and "male". The MesH terms were: "Men's Health", "Professional Competence", "Nursing", "Nursing care" and "Male", using the following crossings from the Boolean operator AND: "Men's health" AND "Professional Competence" AND "Nursing", "Men's health" AND "Professional competence" AND "Nursing care", "Men's health" AND "Nursing care", "Men's health" AND "Male".

Articles available in full, in English, Spanish or Portuguese, with a time frame from 2009 to 2019, considering the historic landmark of PNAISH, promulgated in 2009 have been included. Repeated publications, review studies, conference abstracts, annals, editorials, monographs, dissertations, theses, in addition to studies that did not answer the objective or guiding question of the research outlined and that did not clearly demonstrate the 
nurses'strategies and competencies in men's health care have been excluded.

The screening of studies was done by reading the titles and abstracts, performed by three authors independently, adopting peer review. Subsequently, a consensual discussion and analysis was carried out between them. Finally, publications were assessed through content analysis to survey the synthesis of the knowledge produced. Indexes were not used to assess the coefficient of agreement in the selection of manuscripts. It is reiterated that the selection was guided by a checklist previously prepared with the relevant information from each article considering the research question.

Furthermore, search, including the main databases, took place from the diversified crossing of the descriptors and "MeSH terms" described above. Thorough selection of scientific articles, with well-defined strategies, allowed exclusion of studies that did not answer the objective and guiding question of the research. Those who did not clearly demonstrate nurses' strategies and competencies in men's health care were also excluded, with only the selected studies remaining.

It is noteworthy that the findings were analyzed according to the Nursing Undergraduate Course's DCN, based on Resolution CNE/CES 3, of November 7, 2001, which includes the general and specific skills necessary for the training of nurses. Among these competencies are: health care, decision-making, communication, leadership, administration and management and continuing education. Social health needs were met, with an emphasis on SUS and ensuring comprehensivenss of care, quality and humanization of care, together with PNAISH general and specific principles, guidelines and objectives ${ }^{(10,13)}$.

All results were analyzed and, in case of disagreement, a discussion was held between the evaluators until agreement was reached. The syntax of the study inclusion and exclusion process is described in Figure 1.

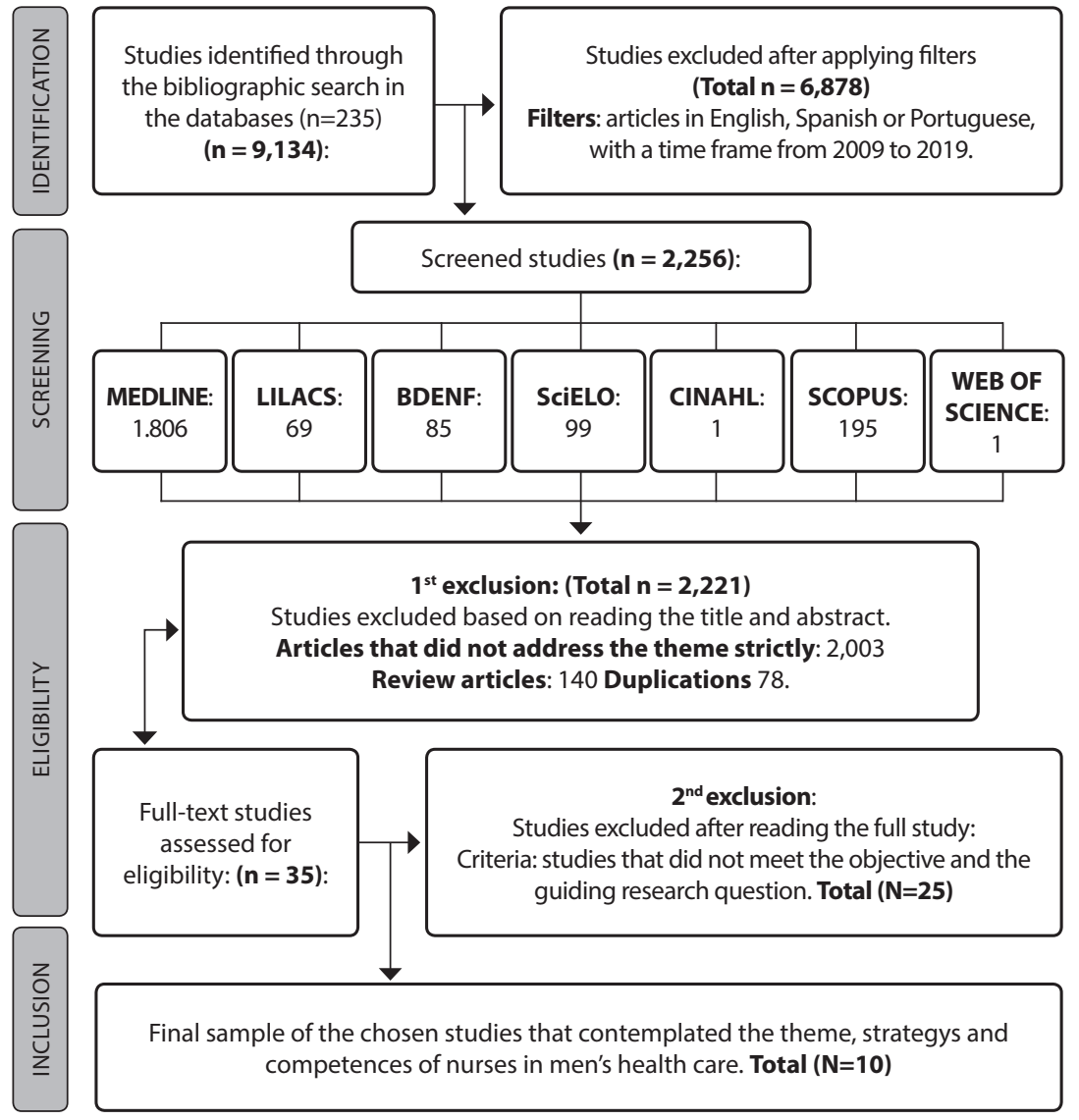

Source: research data, Salvador, Bahia, Brazil, 2019.

Figure 1 - Diagram of selection and identification of studies according to Preferred Reporting Items for Systematic reviews and Meta-Analyzes (PRISMA) recommendations ${ }^{(17)}$

Chart 1 - Characterization of the selected studies according to title, place of study, year of publication and results, Salvador, Bahia, Brazil, 2019

\begin{tabular}{|c|c|c|c|}
\hline $\mathrm{Cl}$ & $\begin{array}{l}\text { Title } \\
\text { Country of Study/ } \\
\text { Year of Publication }\end{array}$ & $\begin{array}{l}\text { Skills } \\
\text { (based on the nursing DCN) }\end{array}$ & $\begin{array}{l}\text { Strategies } \\
\text { (based on PNAISH general and specific } \\
\text { principles, guidelines and objectives) }\end{array}$ \\
\hline A1 & 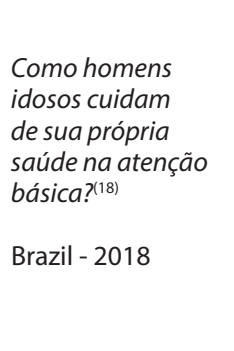 & $\begin{array}{l}\text { General: health care, decision-making, communication, } \\
\text { administration and management, continuing education. Specific: } \\
\text { to understand health policy in the context of social policies; to } \\
\text { recognize health as a right and dignified living conditions and act } \\
\text { in order to guarantee comprehensive care; to act in the health care } \\
\text { program for elderly individuals; to be able to diagnose and solve } \\
\text { problems, to work as a team and to properly use new information } \\
\text { and communication technologies; to identify individual and } \\
\text { collective health needs, being responsible for the quality of nursing } \\
\text { care/care; to plan and implement education and health promotion } \\
\text { programs; interfere in the dynamics of institutional work. }\end{array}$ & $\begin{array}{l}\text { Promoting health education in an efficient } \\
\text { and permanent way to elderly men; offering } \\
\text { incentives to men to better adhere to health } \\
\text { services; adjusting spaces in primary care } \\
\text { for reception; extending consultation hours; } \\
\text { separating care by gender; promoting and } \\
\text { disseminate the November Blue campaign; } \\
\text { provoking and encouraging this specific } \\
\text { population, in order to favor the role of the male } \\
\text { public in health care. }\end{array}$ \\
\hline
\end{tabular}




\begin{tabular}{|c|c|c|c|}
\hline $\mathrm{Cl}$ & $\begin{array}{l}\text { Title } \\
\text { Country of Study/ } \\
\text { Year of Publication }\end{array}$ & $\begin{array}{l}\text { Skills } \\
\text { (based on the nursing DCN) }\end{array}$ & $\begin{array}{l}\text { Strategies } \\
\text { (based on PNAISH general and specific } \\
\text { principles, guidelines and objectives) }\end{array}$ \\
\hline A2 & $\begin{array}{l}\text { Concepção } \\
\text { de saúdee } \\
\text { autocuidado } \\
\text { pela população } \\
\text { masculina de uma } \\
\text { Unidade Básica de } \\
\text { Saúde } \\
\text { Brazil - } 2015\end{array}$ & $\begin{array}{l}\text { General: health care, decision-making, communication. Specific: } \\
\text { to recognize health as a right and dignified living conditions } \\
\text { and act in order to guarantee comprehensive care; to be able to } \\
\text { diagnose and solve health problems, as well as to intervene in the } \\
\text { work process; to promote healthy lifestyles of users/community; to } \\
\text { plan and implement education and health promotion programs; } \\
\text { to recognize the social role of nurses to work in health policy } \\
\text { activities. }\end{array}$ & $\begin{array}{l}\text { Promoting health education; developing } \\
\text { group activities to exchange experiences; } \\
\text { planning health actions together with the } \\
\text { user; encouraging, through health promotion, } \\
\text { healthy habits, socialization and leisure of men. }\end{array}$ \\
\hline A3 & $\begin{array}{l}\text { Ogênero } \\
\text { masculino e os } \\
\text { cuidados de saúde: } \\
\text { a experiência de } \\
\text { homens de um } \\
\text { centro de saúde } \\
\text { Brazil - } 2014\end{array}$ & $\begin{array}{l}\text { General: health care, decision-making, communication. Specific: } \\
\text { to understand health policy in the context of social policies; to } \\
\text { properly use new information and communication technologies; } \\
\text { to integrate nursing actions with multidisciplinary actions; to plan } \\
\text { and implement an education and health promotion program; to } \\
\text { interfere with the dynamics of institutional work. }\end{array}$ & $\begin{array}{l}\text { Improving user service in campaigns; facilitate } \\
\text { understanding of the health-disease process } \\
\text { through guidelines; holding clarification } \\
\text { meetings; offering group care; creating separate } \\
\text { sectors of care for women and children; offering } \\
\text { urology care; extending the service hours. }\end{array}$ \\
\hline A4 & $\begin{array}{l}\text { O homem na } \\
\text { atenção básica: } \\
\text { percepções de } \\
\text { enfermeiros sobre } \\
\text { as implicações do } \\
\text { gênero na saúde } \\
\text { Brazil - } 2014\end{array}$ & $\begin{array}{l}\text { General: health care, decision-making, communication, leadership, } \\
\text { administration and management, Continuing education. Specific: } \\
\text { to develop technical and scientific training; to understand health } \\
\text { policy in the context of social policies; to guarantee comprehensive } \\
\text { care; to be able to diagnose and solve problems, to communicate } \\
\text { and make decisions and to recognize work relationships and their } \\
\text { influence on health; act as a subject in the process of training } \\
\text { human resources; to coordinate the nursing care process; to } \\
\text { implement and participate in training and continuing qualification } \\
\text { programs; to make an ethical, humanistic and social commitment; } \\
\text { to recognize the social role to act in health policy activities. }\end{array}$ & $\begin{array}{l}\text { Promoting holistic and comprehensive care for } \\
\text { men, as well as preventive assistance, aiming } \\
\text { at self-care; bringing health professionals } \\
\text { closer to the environments in which the male } \\
\text { population is concentrated; expanding service } \\
\text { hours; shortening queues and waits; improving } \\
\text { the physical space of services; increasing human } \\
\text { and material resources; encouraging teamwork; } \\
\text { promoting professional training; establishing } \\
\text { partnerships with other institutions; reinforcing } \\
\text { health education actions and campaigns; } \\
\text { improving the approach to technical-scientific } \\
\text { content on men's health at graduation. }\end{array}$ \\
\hline A5 & $\begin{array}{l}\text { Conhecimento } \\
\text { de uma Equipe } \\
\text { da Estratégia } \\
\text { Saúde da Família } \\
\text { sobre A Política de } \\
\text { Atenção à Saúde } \\
\text { masculina } \\
\text { Brazil - } 2014\end{array}$ & $\begin{array}{l}\text { General: health care, decision-making, communication, } \\
\text { leadership, continuing education. Specific: to act professionally } \\
\text { understanding human nature; to develop technical-scientific } \\
\text { training that gives quality to professional practice; to understand } \\
\text { health policy in the context of social policies; to be able to } \\
\text { diagnose and solve health problems, communicate, make } \\
\text { decisions, and work as a team; to recognize itself as coordinator of } \\
\text { the nursing team's work; to develop, participate in research and/or } \\
\text { other forms of knowledge production. }\end{array}$ & $\begin{array}{l}\text { Promoting and implementing the men's } \\
\text { health policy; encouraging and participating } \\
\text { in studies on the theme; qualify primary } \\
\text { care professionals to guarantee assistance } \\
\text { to men; favoring dialogue and exchange } \\
\text { between user-professional; encouraging } \\
\text { transdisciplinarity between different formal and } \\
\text { informal knowledge; improving demands and } \\
\text { services aimed at the male audience; acting } \\
\text { in health education with themes related to } \\
\text { comprehensive care to men's health; promoting } \\
\text { continuing education for workers. }\end{array}$ \\
\hline A6 & $\begin{array}{l}\text { Política de saúde } \\
\text { do homem: } \\
\text { perspectivas } \\
\text { de enfermeiras } \\
\text { para sua } \\
\text { implementação(23) } \\
\text { Brazil - } 2012\end{array}$ & $\begin{array}{l}\text { General: health care, decision-making, leadership, continuing } \\
\text { education. Specific: to understand health policy in the context } \\
\text { of social policies; to recognize work relationships; to respond } \\
\text { to regional health specificities through planned interventions; } \\
\text { to make an ethical, humanistic and social commitment to } \\
\text { multidisciplinary work; to promote healthy lifestyles; to plan } \\
\text { and implement education and health promotion programs and } \\
\text { continuous training programs for nursing workers. }\end{array}$ & $\begin{array}{l}\text { Promoting assistance and educational measures } \\
\text { aimed at changing unhealthy habits of the male } \\
\text { audience; sensitizing this public to the need } \\
\text { for STI prevention, control of gender violence } \\
\text { and reproductive health; integrating social } \\
\text { segments of the men's care network; expanding } \\
\text { service hours and shifts; encouraging teamwork } \\
\text { defining protocols for implementing the } \\
\text { PNAISH; offering training to professionals. }\end{array}$ \\
\hline A7 & $\begin{array}{l}\text { A visão dos } \\
\text { profissionais } \\
\text { sobre a presença } \\
\text { e as demandas } \\
\text { dos homens nos } \\
\text { serviços de saúde: } \\
\text { perspectivas } \\
\text { para a análise da } \\
\text { implantação da } \\
\text { Política Nacional de } \\
\text { Atenção Integral à } \\
\text { Saúde do Homem } \\
\\
\text { Brazil - } 2012\end{array}$ & $\begin{array}{l}\text { General: health care, decision-making, communication, leadership, } \\
\text { continuing education. Specific: to establish new relationships with } \\
\text { the social context; to understand health policy in the context of } \\
\text { social policies; to identify the individual needs of the population, } \\
\text { their conditions and determinants; to manage the nursing work } \\
\text { process with principles of Ethics and Bioethics; to interfere in the } \\
\text { dynamics of institutional work, recognizing itself as an agent of this } \\
\text { process. }\end{array}$ & $\begin{array}{l}\text { Promotion and prevention activities in the } \\
\text { context of the unit's routine operation, offering } \\
\text { care with a urologist that, at times, focuses on } \\
\text { "prostate cancer"; extending the opening hours } \\
\text { of health units; expanding the reference and } \\
\text { counter-reference network; offering continuous } \\
\text { training to professionals about the specificities } \\
\text { of male health. }\end{array}$ \\
\hline
\end{tabular}




\begin{tabular}{|c|c|c|c|}
\hline $\mathrm{Cl}$ & $\begin{array}{l}\text { Title } \\
\text { Country of Study/ } \\
\text { Year of Publication }\end{array}$ & $\begin{array}{l}\text { Skills } \\
\text { (based on the nursing DCN) }\end{array}$ & $\begin{array}{l}\text { Strategies } \\
\text { (based on PNAISH general and specific } \\
\text { principles, guidelines and objectives) }\end{array}$ \\
\hline A8 & $\begin{array}{l}\text { A Saúde do } \\
\text { Homem na visão } \\
\text { dos Enfermeiros } \\
\text { de uma Unidade } \\
\text { Básica de Saúde } \\
\text { Brazil - } 2012\end{array}$ & $\begin{array}{l}\text { General: health care, decision-making, communication, leadership, } \\
\text { administration and management, continuing education. Specific: to } \\
\text { properly use new technologies; to identify the individual and collective } \\
\text { health needs of the population, their conditions and determinants; } \\
\text { to coordinate the nursing care process, considering health contexts } \\
\text { and demands; to manage the nursing work process with principles } \\
\text { of Ethics and Bioethics, with resolution both at the individual and } \\
\text { collective level; to interfere with the dynamics of institutional work, } \\
\text { recognizing itself as an agent of this process; to use the instruments } \\
\text { that guarantee the quality of nursing care and health care. }\end{array}$ & $\begin{array}{l}\text { Carrying out programs or activities available } \\
\text { specifically for the male population; promoting } \\
\text { comprehensive assistance to men; providing } \\
\text { adequate space and physical structure to } \\
\text { welcome and serve the male clientele; offering } \\
\text { urology care; promoting health education to } \\
\text { users and continuing education, in order to train } \\
\text { professionals to care for men's health. }\end{array}$ \\
\hline A9 & $\begin{array}{l}\text { Discussing a } \\
\text { sensitive topic: } \\
\text { Nurse practitioners' } \\
\text { and physician } \\
\text { assistants' } \\
\text { communication } \\
\text { strategies in } \\
\text { managing patients } \\
\text { with erectile }^{\text {dysfunction }}{ }^{(26)} \\
\text { Ireland - } 2009\end{array}$ & $\begin{array}{l}\text { General: health care, decision-making, communication, continuing } \\
\text { education. Specific: to establish new relationships with the } \\
\text { social context; to recognize health as a right and dignified } \\
\text { living conditions and act in order to guarantee comprehensive } \\
\text { care; to make an ethical, humanistic and social commitment to } \\
\text { multidisciplinary health work; to be able to diagnose and solve } \\
\text { health problems; to intervene in the work process and to work as } \\
\text { a team. }\end{array}$ & $\begin{array}{l}\text { Participating in continuing education programs; } \\
\text { deepening knowledge about sexual and } \\
\text { urological disorders and problems; promoting } \\
\text { bonding between user-nurse; allowing better } \\
\text { communication when approaching men so } \\
\text { that they verbalize and question about erectile } \\
\text { disorder; overcoming cultural and linguistic } \\
\text { barriers; planning assistance by allocating time } \\
\text { for health promotion and education to the male } \\
\text { audience. }\end{array}$ \\
\hline A10 & $\begin{array}{l}\text { Working patterns } \\
\text { and perceived } \\
\text { contribution of } \\
\text { prostate cancer } \\
\text { clinical nurse } \\
\text { specialists: A } \\
\text { mixed method } \\
\text { investigation }{ }^{(27)} \\
\text { United Kingdom } \\
\text { - } 2009\end{array}$ & $\begin{array}{l}\text { General: health care, decision-making, communication, leadership, } \\
\text { continuing education. Specific: to establish new relationships with } \\
\text { the social context, recognizing the structure and forms of social } \\
\text { organization; to develop technical-scientific training that gives } \\
\text { quality to professional practice; to understand health policy in the } \\
\text { context of social policies; to coordinate the nursing care process; to } \\
\text { be able to diagnose and solve health problems; to intervene in the } \\
\text { work process and to work as a team. }\end{array}$ & $\begin{array}{l}\text { Participating in specific qualification and } \\
\text { training in assistance in areas specific to men's } \\
\text { health that include oncology and urology; } \\
\text { providing physical intervention when necessary } \\
\text { coordinating and planning nursing care for } \\
\text { users; meeting the unique demands and needs } \\
\text { of the male clientele through welcoming, } \\
\text { counseling, adequate communication, sensitive } \\
\text { listening, emotional support, negotiation, and } \\
\text { health education. }\end{array}$ \\
\hline
\end{tabular}

Note: DCN - National Curriculum Guidelines; PNAISH - National Policy for Integral Attention to Men's Health; *STI - Sexually Transmitted Infection.

The selected articles were concentrated in 2014, 2012 and 2009, respectively. Most were published in Portuguese, in nursing journals, carried out in the Southeast of Brazil, in Ireland and in the United Kingdom. It is noteworthy that studies that had female nurses as the main research participants predominated.

\section{DISCUSSION}

The development of professional skills nurses aims at a qualified professional configuration, based on rigorous bases of scientific knowledge and guided by ethical principles, as established in the DCN of the Undergraduate Nursing Course. Accordingly, the scientific literature includes studies in other countries that also corroborate these Brazilian guidelines. It is emphasized that general and specific competences contribute to the adequate performance of the functions of professional nurses and greater resolution of present and future social demands of the population ${ }^{(28,29.30)}$.

With regard to men's health care, it is noted that the professional skills and strategies implemented by nurses, in the field of practice, are centered on the basic level of health care, when observing Brazilian articles ${ }^{(18-22,25)}$. In turn, at the international level, nursing care production is applied to specialized care ${ }^{(26,27)}$.

Initially, it is worth asking why there is a specific focus on male health care. The justification is based on the discrepancy in life expectancy and mortality between men and women. Even in countries like Ireland, which has stood out for being the first country in the world to institute a specific health policy for men, there has been a decrease in male life expectancy over the years. However, preventive health actions have been shown to be very effective, especially when started early, with boys ${ }^{(31)}$.

In terms of competences, health care is highlighted as a general competence of nurses, which is configured in the professional performance based on individual and collective care. It is guaranteed the highest quality standards, in line with ethical and bioethical principles. It is a level of care that provides for the resolution of problems not only through the technical act, but also through the development of prevention, promotion, protection and health rehabilitation actions, in an integrated and continuous way with the other instances of health services ${ }^{(13)}$.

An Italian study carried out in the workplace with a predominantly male population proposed an educational intervention to reduce cardiovascular risk. It was discovered, even 12 months after the end of the intervention, that the effects were still observed ${ }^{(32)}$. The efficiency and importance of actions based on promotion and prevention within the scope of men's health care is proven, as well as other research developed internationally ${ }^{(33,34)}$.

The scope of this competence closely converges with PNAISH principles and guidelines. PNAISH recommends proposals 
capable of outlining lines of action to be followed in the health sector with a view to meeting the health demands of the male public ${ }^{(10)}$. However, to achieve these results, it is necessary to guarantee action comprehensiveness based on observance of feasibility, coherence and viability in the daily services and production of care.

It is also emphasized the need for the strategies implemented by nurses to be guided by humanization and aim to improve the quality of assistance to the male public. Therefore, it will promote the integration of PNAISH performance with the other public policies, programs and actions to be deliberated by the competent bodies, such as the Ministry of Health $(\mathrm{MoH})^{(10)}$.

Therefore, as a way of ensuring competence exercise to promote health care, it is necessary that professional nurses act in favor of strengthening the expansion of access and adherence to health services; adjust the service through the gender marker; offer care directed to urological care; extend service hours; strengthen the network to guarantee reference and counter-reference; expand and publicize campaigns in the month known as Blue November ${ }^{(18-25)}$.

However, it is noteworthy that these strategies are not necessarily carried out, in practice, by professional nurses, but they were sometimes cited by them as liable to future implementation. The studies also revealed some difficulties faced in men's health care, largely to access and raise awareness among the male public, due to low adherence; unavailability of schedules by this public to seek help in services; and discreet construction of a culture of seeking care. Accordingly, similar results in other studies also mentioned these hindering factors ${ }^{(35-37)}$.

To act to guarantee the competence to promote men's health care is to meet the expansion of this public's access to health services. This is done in a hierarchical manner at all levels of care, through health network organization to ensure the resolution of problems and the monitoring of them by health teams. It is part of PNAISH principles articulation between the different areas of the government as well as the private sector and society. It is a way to enhance care network composition and ensure co-responsibility with regard to quality of life and health promotion for men ${ }^{(10)}$.

Regarding decision-making, it is a general competence of the nurse's professional practice that must be exercised; it comprises appropriate use of the effectiveness and cost-effectiveness ratio, workforce, use of medicines, equipment, procedures and practices. It is an essential competence and, to achieve it, nurses must develop skills that allow them to assess and systematize, supported by scientific evidence ${ }^{(13)}$.

A survey of 23 African American adult men in Texas had, with one of its objectives, to analyze attitudes towards health management. It was found that the participants themselves identified the benefits of nurses' decision-making competence as a way to avoid future health problems. In addition, the results of this study indicated that health management behaviors in men are multifaceted. It is necessary that health professionals understand these factors, welcome and talk to the male audience, in order to add treatment strategies that are culturally relevant, effective and focused on the patient and their specificities ${ }^{(38)}$.

Like decision-making, leadership emerges as a nurse's general competence. It relates to the multidisciplinary work in which the nursing profession is inserted, requiring the ability to take over leadership positions. Commitment, responsibility, empathy, ability to make decisions, communication and management of care effectively and efficiently are involved in the competent exercise of leadership ${ }^{(13)}$.

As a way of supporting decision-making and ensuring the exercise of leadership in nursing, Law 7,498 of 1986, which regulates the exercise of the profession, exclusively assigns to the nurse the direction of nursing organs in public and private institutions, the organization and direction of services, as well as the planning, coordination, execution and assessment of nursing care services as part of the health team, which gives it greater professional visibility and expands its performance in the job market ${ }^{(39)}$.

These attributions are recognized as important by professional nurses, who have demonstrated, in the studies analyzed, to use them to favor health care production for men in several ways: planning actions together with the male population; holding meetings with the community in order to reduce unknowns to the target population; encouraging men as a way to enhance adherence to services; strengthening health campaigns and promoting innovative and attractive interventions to reach and raise awareness among this public ${ }^{(21,22,24,25)}$. In conjunction with these strategies, PNAISH advocates encouraging interinstitutional articulation, with emphasis on the education sector, as it is a significant promoter of new ways of thinking and acting in the face of men's health care ${ }^{(10)}$.

Moreover, the need is emphasized for nurses to seek to reorganize health actions based on the inclusion of men in services, promoting male spaces and recognizing the diversity of care demanded by them ${ }^{(10)}$. In Canada, for instance, the provision of primary care in remote communities has been supported by nurses who work to ensure health promotion, conduct clinical assessment and promote community health nursing, as well as to plan and implement health care programs. health ${ }^{(40)}$.

It is also relevant to capture men early, through the performance of focal activities, especially related to the primary prevention of diseases and other specific clinical contexts of the male audience, investing in the technical training of health teams that provide care ${ }^{(10)}$. Finally, the integration of organized civil society spheres should be included by nurses, in order to strengthen the co-responsibility of health actions, in support of the State, in a movement to promote citizenship.

When analyzing the development of communication competence, also foreseen in nursing DCN, verbal and non-verbal communication and the skills of writing, reading and using communication and information technologies stand out. They must be accessible and reliable, in integration with the other health professionals on the team and the assisted public ${ }^{(13)}$. Thus, it was evident in this study that, in order to achieve this competence, nurses seek to promote and facilitate the understanding of the health and disease process by the male population and expand the dialogue on sensitive topics such as sexual dysfunction. Nurses also revealed to promote, in addition to information and advice to men and their families, overcoming cultural and linguistic barriers; to develop health education in a broad and permanent way, in order to overcome the reductionist attention focused only on prostate cancer; to invest in promoting group 
activities to enhance the dialectical relationship and the exchange of experiences; and to strengthen the dissemination of health

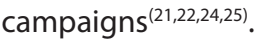

Under this logic, PNAISH establishes some paths for the fulfillment of its principles, one of which is the production of information and guidelines directed to the male population, their families and the community, in order to maximize promotion, prevention and treatment of diseases and illnesses that affect men ${ }^{(10)}$. Such recommendation points to the need for professional nursing practice that puts communication competence into practice, enhancing the relational aspect, such as subjectivity, establishing bonds and reducing barriers to production of health care.

Intertwined with the communication competence, as well as the others already mentioned, the ability to administer and manage the workforce, physical/material resources and information stands out as a unique competence for nurses ${ }^{(13)}$. The studies analyzed reported the presence of factors that hinder the exercise of professional practice, especially the lack of adequate spaces in the service to welcome users, lack of materials, supplies, medicines, managerial support and dissemination of strategies planned to promote the men's health ${ }^{(21,22,24-27)}$.

However, despite these difficulties, nurses have been shown to produce health care for men in several ways: through teamwork; carrying out health education campaigns and activities aimed at men; promoting consultations with specialists in urology; and the provision of assistance in a specific and humanized way in the services of specialties for male care ${ }^{(21,22,24-27)}$. As a way of reiterating the need for these professionals to develop and exercise this competence, PNAISH stresses that availability of inputs, equipment and educational materials by federal agencies must be considered, which leads to a professional activity of proactivity and governance in occupied position ${ }^{(10)}$.

The establishment of political mechanisms for continuous monitoring and assessment of services is highlighted, as well as performance of professionals in conjunction with users. These are actions that also guarantee production of specific health indicators, capable of expressing health scenarios, assessing the impacts of the strategies and actions developed and directing (re)organization of professional practices ${ }^{(10)}$.

A study carried out in three Brazilian capitals revealed strategies for promoting men's health developed under three axes of attention. The first is aimed at attracting those users who have little time available to stay in health services, through a relationship of trust, permeated by a relationship of exchange and offer of material encouragement such as "care kit" offer (products hygiene and care in general); the second aims to insert them in their own care, by approaching this audience during prenatal care and family planning activities, expanding routine clinical examinations, valuing paternity, adapting language and displacing health professionals to care in spaces where these users are more present, such as work; finally, the third axis aims at deconstructing hegemonic masculinity patterns and meeting the specific demand, for example, for contraception ${ }^{(41)}$.

Concerning continuing education as a general competence to be developed within the scope of professional nurses, it must be recognized and exercised as the capacity to learn continuously, in training and in practice. Responsibility and commitment must be directed to education, in order to promote benefits between professionals and network cooperation, nationally and internationally ${ }^{(13)}$.

Therefore, the present study showed that, although nurses develop strategies to promote and strengthen men's health education, they face difficulties to achieve this goal. They are lack of professional training, absence of specific protocols for serving the male population in services and lack access to areas of professional specialization, for instance, urology/andrology ${ }^{(18-27)}$

Among the selected studies, those produced outside Brazil explore male urological health care, focused on specialized care, at the level of secondary health care. However, in the Brazilian scenario, studies point to the development of actions essentially produced in Primary Health Care, which indicates the breadth of community care production, centered on the person, family and community, in which it is also organized and structured the PNAISH. Another relevant point of observation is due to the fact that studies of the profile of the health situation of men pointed out that the male audience enters the services of secondary and tertiary care with greater prevalence. There is still a gap in knowledge regarding the development of actions with men, at these levels, in the health system.

Understanding this gap in investments in continuing education of nurses, a survey in the United States of America identified weaknesses in the development of this competence in the thematic area of men's health, still in the academy. A specialized curriculum in men's health based on consensus between universities, particularly in professional health programs, is paramount ${ }^{(42)}$. Such problem can have repercussions on the decline and even on the fragility and invisibility in the advancement of scientific production directed to the area. It can be observed in this study, when analyzing the decrease in Brazilian publications, which consider the gender perspective in the health dimension of from PNAISH implementation.

In line with this nursing competence, PNAISH foresees the inclusion of continuing education for SUS workers with themes related to Comprehensive Care to Men's Health. However, it is important to highlight that these Continuing education actions have been implemented by $\mathrm{MoH}$ at a late stage, in which the training courses carried out in the distance modality by Open University of SUS (Universidade Aberta do SUS, abbreviated UNASUS) stand out. Moreover, there is still no available the Primary Care booklet, aimed at men's health care, to be used by health professionals, present at this level of care.

However, even in the face of these obstacles, it is noticeable in Brazil, especially after 2016, the development of devices for health promotion and production of care directed to the male public by $\mathrm{MoH}$. It includes carrying out a specific study to raise the profile of health and male mortality, in a thematic glossary type of men's health. Other actions involved the elaboration of the following materials: guide for reproductive planning, prenatal care, childbirth and child development with working men; men's health guide for Community Health Agents (CHA); and partner's prenatal guide for health professionals ${ }^{(43-46)}$.

As a strategy to overcome problematic issues that affect men's health, in the Irish context, increased attention has been developed to the framework of actions aimed at this population as a 
way to boost the construction of a place of greater visibility. It is an initiative that comes out of the discourse and takes action, through governance based on practice ${ }^{(47)}$.

Australia also presents a favorable scenario with regard to male health, since Australians are over 80 years old and actions have been implemented to promote specialized care to specific population groups. As part of the strategies developed, systematic attention, effective implementation of the national male health policy and incorporation of a gender lens to assess specific problems and needs of men, with a view to long-term planning. In this case, for strategies to be developed between 2020 and $2030^{(6)}$.

Thus, given the above and the findings in scientific literature, nurses in men's health care is important, as they are the protagonist of the care process at different levels, aiming at specialized, medium and high care complexity and acting in promoting health and preventing diseases of the male population. Thus, the development relevance of general and specific skills in men's health care is notorious, in order to broaden the view of this subject who not only presents specificities and particular demands but requires nurses to pay singular attention in order to overcome socio-cultural barriers and to foster strategies for better adherence, reception, assistance, listening and involvement of men in health services.

\section{Study limitations}

It was identified as limitations of the study absence of assessment on the quality of the articles included in the review and production gap related to the explored theme. Also, use of only controlled terms, without adding common language synonyms (keywords) as well as use of the operator by scoring OR between descriptors and keywords that refer to the same element of the acronym PPC. It was necessary to expand the search to include the main databases and expand the number of descriptors and $\mathrm{MeSH}$ terms, using diversified crossings between them. Thorough search with well-defined strategies, such as exclusion of studies that did not answer the objective and guiding question of the research, in addition to those that did not clearly show the nurses' strategies and skills in men's health care, restricted the inclusion of selected studies.

\section{Contributions to nursing, health, and public policies}

This study brings significant contributions to the practice of nursing and public health, through the survey of scientific evidence on professional competences and skills that enhance (re) direction, planning, organization, performance, and assessment of actions for the production of care and attention to men's health.

\section{FINAL CONSIDERATIONS}

This study synthesized scientific evidence on the skills and abilities of nurses in men's health care. It was revealed that professional nurses develop their professional practices with regard to men's health care in convergence with the general skills of the profession, implementing strategies to improve male health care, in line with PNAISH principles and guidelines.

\section{REFERENCES}

1. Griffith DM, Gilbert KL, Bruce MA, Thorpe RJ. Masculinity in men's health: barrier or portal to healthcare?. In Heidelbaugh J. Men's health in primary care. Humana Press, Cham. 2016;19-31. doi: 10.1007/978-3-319-26091-4_2

2. Beltrán-Sánchez H, Finch CE, Crimmins EM. Twentieth century surge of excess adult male mortality. National Academy of Sciences. 2015;112(29):8993-8. doi: 10.1073/pnas.1421942112

3. Oliveira JC, de Paula Correa ÁC, Arruda L, Mozer IT, Medeiros RM. Perfil epidemiológico da mortalidade masculina: contribuições para enfermagem. Cogitare Enferm. 2017;22(2). doi: 10.5380/ce.v22i2.49742

4. Stevens GA, Alkema L, Black RE, Boerma J, Collins GS, Ezzati M, et al. Guidelines for Accurate and Transparent Health Estimates Reporting: the GATHER Statement. Epidemiol Serv Saude. 2017;26(1):215-22. doi: 10.5123/s1679-49742017000100023

5. Rosu MB, Oliffe JL, Kelly MT. Nurse practitioners and Men's primary health care. Int J Mens Health. 2017;11(5):1501-11. doi: $10.1177 / 1557988315617721$

6. Baker PE. Review of the National Men's Health policy and Action Plan 2008-2013. Health Service Executive: Dublin [Internet]. 2015 Mar [cited 2015 July 04]. Available from: http://gamh.org/wp-content/uploads/2015/07//reland-Mens-Health-Policy-Review.Final-Full-Report.2015.pdf

7. Ministério do Planejamento, Orçamento e Gestão (BR), Instituto Brasileiro de Geografia e Estatística. Tábua completa de mortalidade para o Brasil - 2017 [Internet]. Rio de Janeiro: IBGE; 2017 [cited 2019 Jun 15]. Available from: ftp://ftp.ibge.gov.br/Tabuas_Completas_de_ Mortalidade/Tabuas_Completas_de_Mortalidade_2017/tabua_de_mortalidade_analise.pdf

8. Fraga JCAXO, Corrêa ACP, Rocha RM, Silva LA, Medeiros RMK, Mozer IT. Principais causas da mortalidade masculina e os anos potenciais de vida perdidos por estes agravos. Cienc Cuid Saude. 2016;15(4):746-54. doi: 10.4025/cienccuidsaude.v15i4.34354

9. Moura EC, Lima AM, Urdaneta M. Uso de indicadores para o monitoramento das ações de promoção e atenção da Política Nacional de Atenção Integral à Saúde do Homem (PNAISH). Ciênc. Saúde Colet. [Internet]. 2012 Jul [cited 2019 Jun 09];17:2597-606. Available from: https://www.scielosp.org/scielo.php?pid=S1413-81232012001000009\&script=sci_arttext\&tlng=pt\#

10. Ministério da Saúde (BR). Secretaria de Atenção à Saúde. Departamento de Ações Programáticas Estratégicas. Política nacional de atenção integral à saúde do homem: princípios e diretrizes. Brasília: Editora do Ministério da Saúde [Internet]. 2009 Jul [cited 2019 Jun 09]. Available from: http://bvsms.saude.gov.br/bvs/publicacoes/politica_nacional_atencao_homem.pdf 
11. Rosa Mesquita MG, Paes GO, da Silva MM, da Costa S, Duarte M, Erdmann AL, et al. Gerência do cuidado de enfermagem ao homem com câncer. Rev Pesqui Cuid Fundam. 2015;7(3):2949-60. doi: 10.9789/2175-5361.2015.v7i3.2949-2960

12. Montezeli J, Peres A, Bernardino E. Competências gerenciais requeridas de enfermeiros em um pronto-socorro. Rev Pesqui Cuid Fundam. 2013;5(3):245-52. doi: 10.9789/2175-5361.2013.v5i3.245-252

13. Ministério da Educação (BR), Conselho Nacional de Educação. Resolução n. 3, de 07 de novembro de 2001. Diretrizes curriculares nacionais do curso de graduação em Enfermagem [Internet]. Diário Oficial da União: República Federativa do Brasil; 2001 [cited 2019 Jul 02]. Available from: http://www.cofen.gov.br/wpcontent/uploads/2012/03/resolucao_CNE_CES_3_2001Diretrizes_Nacionais_Curso_Graduacao_ Enfermagem.pdf

14. Mendes KD, Silveira RC, Galvão CM. Revisão integrativa: método de pesquisa para a incorporação de evidências na saúde e na enfermagem. Texto Contexto Enferm. 2008;17(4):758-64. doi: 10.1590/S0104-07072008000400018

15. Joanna Briggs Institute (JBI). Methodology for JBI Scoping Reviews - Joanna Briggs 2015 [Internet]. Australia: JBI; 2015 [cited 2015 Jul 04 ]. Available from: http://joannabriggs.org/assets/docs/sumari/Reviewers-Manual_Methodology-for-JBI-Scoping-Reviews_2015_v2.pdf

16. Ogrinc G, Davies L, Goodman D, Batalden P, Davidoff F, Stevens D. SQUIRE 2.0 (Padrões para Excelência de Relato de Melhorias em Qualidade): revisaram as diretrizes de publicação de um processo de consenso detalhado. Rev Educ Contin Enferm. 2015;46(11):501-7. doi: 10.1136/bmjqs-2015-004411

17. Liberati A, Altman DG, Tetzlaff J, Mulrow C, Gøtzsche PC, loannidis JPA, et al. The Prisma statement for reporting systematic reviewsand meta-analyses of studies that evaluate health care interventions: explanation and elaboration. PLoS Med. 2009;6(7):e1000100. doi: 10.1371/ journal.pmed.1000100

18. Sousa Queiroz T, Morais Santa Barbara Rehem TC, Morato Stival M, Schwerz Funghetto S, Ramos de Lima L, Guilherme Cardoso B ,et al. Como homens idosos cuidam de sua própria saúde na atenção básica? Rev Bras Enferm. 2018;71. doi: 10.1590/0034-7167-2017-0131

19. Xavier SQ, Ceolin T, Echevarría-Guanilo ME, da Costa Mendieta M. Concepção de saúde e autocuidado pela população masculina de uma Unidade Básica de Saúde. Enferm. Glob. 2015; 14(4):44-75. doi: 10.6018/eglobal.14.4.193091

20. Bertolini DN, Simonetti JP. O gênero masculino e os cuidados de saúde: a experiência de homens de um centro de saúde. Esc Anna Nery. 2014;18(4):722-7. doi: 10.5935/1414-8145.20140103

21. Albuquerque GA, Leite MF, Belém JM, Nunes JF, Oliveira MA, Adami F. O homem na atenção básica: percepções de enfermeiros sobre as implicações do gênero na saúde. Esc Anna Nery. 2014;18(4):607-614. doi: 10.5935/1414-8145.20140086

22. Souza LP, Almeida ER, Queiroz MA, Silva JR, Souza AA, Figueiredo MF. Conhecimento de uma equipe da estratégia saúde da família sobre a política de atenção à saúde masculina. Trab. Educ. Saúde. 2014;12(2):291-304. doi: 10.1590/S1981-77462014000200005

23. Alvarenga WA, Santos S, Costa Silva ME, Costa LD, Barbosa S, Rocha SS. Política de saúde do homem: perspectivas de enfermeiras para sua implementação. Rev Bras Enferm. [Internet]. 2012 [cited 2019 Jul 02];65(6):929-35. Available from: https://www.scielo.br/pdf/reben/v65n6/ a07v65n6.pdf

24. Knauth DR, Couto MT, Figueiredo WD. A visão dos profissionais sobre a presença e as demandas dos homens nos serviços de saúde: perspectivas para a análise da implantação da Política Nacional de Atenção Integral à Saúde do Homem. Ciênc Saúde Colet. 2012;17:261726. doi: 10.1590/S1413-81232012001000011

25. Silva PA, Furtado MD, Guilhon AB, Souza NV, David HM. A saúde do homem na visão dos enfermeiros de uma unidade básica de saúde. Esc Anna Nery [Internet]. 2012 [cited 2019 Jul 03];16(3):561-8. Available from: http://www.scielo.br/pdf/ean/v16n3/19

26. Green R, Kodish S. Discussing a sensitive topic: Nurse practitioners' and physician assistants' communication strategies in managing patients with erectile dysfunction. J Am Acad Nurse Pract. 2009;21(12):698-705. doi: 10.1111/j.1745-7599.2009.00464.x

27. Ream E, Wilson-Barnett J, Faithfull S, Fincham L, Khoo V, Richardson A. Working patterns and perceived contribution of prostate cancer clinical nurse specialists: a mixed method investigation. Int J Nurs Stud. 2009;46(10):1345-54. doi: 10.1016/j.ijnurstu.2009.03.006

28. Dandicourt Thomas C. Competencias profesionales para el especialista de Enfermería Comunitaria en Cuba. Rev Cuba Enferm [Internet]. 2016 [cited 2015 Jul 04];32(1):16-26. Available from:https://www.medigraphic.com/pdfs/revcubenf/cnf-2016/cnf161c.pdf

29. Sánchez-Gómez MB, Duarte-Clíments G, Aguirre-Jaime A, Sierra-López A, Arias-Rodríguez Á, De Armas-Felipe JM. Análisis cualitativo de las competencias para la especialidad de Enfermería Familiar y Comunitaria. Construyendo el camino hacia la enfermería clínica avanzada. Rev ENE Enferm. 2012 [cited 2015 Jul 04]26;6(2):39-70. Available from: http://www.ene-enfermeria.org/ojs/index.php/ENE/article/view/18/16

30. Dandicourt Thomas C, Sarria YM, Esperón MT. Observación en la práctica de funciones para el especialista en Enfermería Comunitaria. Rev Cuba Enferm[Internet]. 2012 [cited 2015 Jul 04];28(3):228-42. Available from: https://www.medigraphic.com/pdfs/revcubenf/cnf-2012/ cnf123f.pdf

31. Richardson N, Carroll P. National Men's Health Action Plan Healthy Ireland-Men HI-M 2017-2021 Working with men in Ireland to achieve optimum health and wellbeing [Internet]. 2016 [cited 2015 Jul 04]. Available from: https://www.mhfi.org/HI-M.pdf

32. Mastrangelo G, Marangi G, Bontadi D, Fadda E, Cegolon L, Bortolotto M, Fedeli U, Marchiori L. A worksite intervention to reduce the cardiovascular risk: proposal of a study design easy to integrate within Italian organization of occupational health surveillance. BMC public health. 2015;15(1):12. doi: 10.1186/s12889-015-1375-4

33. Stockings E, Hall WD, Lynskey M, Morley KI, Reavley N, Strang J, Patton G, Degenhardt L. Prevention, early intervention, harm reduction, and treatment of substance use in young people; Lancet Psychiatry. 2016;3(3):280-96. doi: 10.1016/S2215-0366(16)00002-X 
34. O'Brien AP, Hurley J, Linsley P, McNeil KA, Fletcher R, Aitken JR. Men's preconception health: a primary health-care viewpoint. Am J Men's Health. 2018;12(5):1575-81. doi: 10.1177/1557988318776513

35. Teixeira DB. Atenção à saúde do homem: análise da sua resistência na procura dos serviços de saúde. Rev Cuba Enferm [Internet]. 2016 [cited 2015 Jul 04];32(4). Available from: http://revenfermeria.sld.cu/index.php/enf/article/view/985

36. Leone JE, Rovito MJ, Mullin EM, Mohammed SD, Lee CS. Development and testing of a conceptual model regarding men's access to health care. Int J Mens Health. 2017;11(2):262-74. doi: 10.1177/1557988316671637

37. Thompson T, Mitchell JA, Johnson-Lawrence V, Watkins DC, Modlin Jr CS. Self-rated health and health care access associated with African American men's health self-efficacy. Int J Mens Health. 2017;11(5):1385-7. doi: 10.1177/1557988315598555

38. Amuneke-Nze CG, Bamgbade BA, Barner JC. An Investigation of Health Management Perceptions and Wellness Behaviors in African American Males in Central Texas. Int J Mens Health. 2019;13(1):1557988318813490. doi: 10.1177/1557988318813490

39. Presidência da República (BR). Lei $n^{\circ} 7.498$, de 25 de junho de 1986. Regulamentação do exercício da enfermagem e dá outras providências [Internet]. Diário Oficial da República Federativa do Brasil. Brasília (DF); 1986 [cited 2019 Jul 02]. Available from: http://www.cofen.gov.br/ lei-n-749886-de-25-de-junho-de-1986_4161.html

40. Government of Canada (CA). Adult Care: Clinical Practice Guidelines for Nurses in Primary Care. First Nations and Inuit Health Branch (FNIHB). Government of Canada; 2011 [cited 2019 July 02]. Available from: https://www.canada.ca/en/indigenous-services-canada/services/ first-nations-inuit-health/health-care-services/nursing/clinical-practice-guidelines-nurses-primary-care.html

41. Moreira MC, Gomes R, Ribeiro CR. E agora o homem vem?! estratégias de atenção à saúde dos homens. Cad Saúde Pública. 2016;32:e00060015. doi: 10.1590/0102-311X00060015

42. Giorgianni Jr SJ, Porche DJ, Williams ST, Matope JH, Leonard BL. Developing the discipline and practice of comprehensive men's health. Int J Mens Health. 2013;7(4):342-9. doi: 10.1177/1557988313478649

43. Ministério da Saúde (BR). Secretaria de Atenção à Saúde. Departamento de Ações Programáticas Estratégicas. Perfil da morbimortalidade masculina no Brasil [Internet]. Brasília: Ministério da Saúde; 2018 [cited 2019 Jul 02]. Available from: http://portalarquivos2.saude.gov.br/ images/pdf/2018/fevereiro/19/Perfil-da-morbimortalidade-masculina-no-Brasil.pdf

44. Ministério da Saúde (BR). Secretaria de Atenção à Saúde. Departamento de Ações Programáticas Estratégicas. Como envolver o homem trabalhador no planejamento reprodutivo, pré-natal, parto e desenvolvimento da criança [Internet]. Brasília: Ministério da Saúde; 2018 [cited 2019 Jul 02]. Available from: http://portalarquivos2.saude.gov.br/images/pdf/2016/agosto/11/guia_PreNatal.pdf

45. Hermann A, Silva M, Chakora E, Lima D. Guia para pré-natal do parceiro para profissionais de saúde [Internet]. Rio de Janeiro: Ministério da Saúde; 2016 [cited 2019 Jul 02]. Available from: http://portalarquivos2.saude.gov.br/images/pdf/2016/agosto/11/guia_PreNatal.pdf

46. Herrmann A (Coord). Guia de Saúde do Homem para Agente Comunitário de Saúde (ACS) [Internet]. Rio de Janeiro: Ministério da Saúde; 2016[cited 2019 Jul 02]. Available from: https://central3.to.gov.br/arquivo/369121/

47. Richardson N, Smith JA. National men's health policies in Ireland and Australia: what are the challenges associated with transitioning from development to implementation? Public Health. 2011;125(7):424-32. doi: 10.1016/j.puhe.2011.04.015 